\title{
CARA MASYARAKAT TRANSMIGRASI ASAL BALI \\ DALAM MENTAATI NORMA HUKUM YANG DIBAWA DENGAN HUKUM ADAT \\ SETEMPAT DI KECAMATAN BASARANG KABUPATEN KAPUAS \\ Oleh : I Made Kastama*
}

\begin{abstract}
Abstrak
Secara umum semua aturan hukum memiliki tujuan yang sama yaitu sama-sama inginmenciptakan keamanan, ketertiban, ketentraman, keadilan serta keseimbangan lahir dan bhatin, sehingga semua aturan hukum memiliki tujuan yang sangat baik. Aturan hukum yang baik adalah aturan hukum yang mampu hidup dan terima di tengah-tengah kehidupan masyarakat. AturanhukumatauNorma hukum yang berlaku di tengah-tengan kehidupan masyarakatsangat menentukan terwujuddantercapainyaketentraman, ketertiban dan keamanan bagi masyarakat terutama masyarakat yang sering mengalami permasalahan-permasalahan sebagai akibat kebutuhan hidup yang selalu berkembang dansetiapmasyarakat sangat memerlukan perlindungan kepentingan manusia.Agar hubungan kehidupan bermasyarakat tetap harmonis setiap warga masyarakat wajib untuk menghormati norma hukum-norma hukum yang hidup dalam masyarakat, seimbang dan harmonisnya hubungan masyarakat diperlukan pentaatan pada aturan yang berlaku.

Masyarakat lebih aman mentaati aturan dari pada tidak mentaati norma hukum apalagi sampai melanggarnya, aturan hukum masyarakat manapun yang diberlakukan kita wajib untuk mentaatinya. Cara masyarakat Transmigasi asal Bali dalam mentaati Norma Hukum terutama Hukum Adat dan Hukum Agama yang dibawa dengan Hukum Adat setempat adalah dengan cara mentaati semua paraturan yang diberlakukan oleh lembaga yang berwenang, masyarakat transmigrasi asal Bali sangat mentaati hukum Hindu/adat Bali karena kedua hukum itu telah berasimilasi dan diimplementasikan dalam organisasi Banjar dan sebagai masyarakat Kalimantan Tengah masyarakat Transmigrasi asal Bali tentu juga mentaati hukum adat dayak yang berpegang teguh pada slogan dimana bumi dipijak disitu langit dijunjung.
\end{abstract}

\section{Kata Kunci : Norma hukum, mentaati dan masyarakat transmigrasi}


*Dosen pada Program Pascasarjana STAHN-TP Palangka Raya

\section{Pendahuluan}

Kehidupanmanusiadalammasyarakatcenderunguntuk mentaati hukum yang berlaku merupakan karenamerupakankewajiban sebagai warga negara Indonesia. Sebagai masyarakat yangtaatdan sadar dengan keberadaan hukum maka untuk mentaati hukum tidak perlu sampaidipaksakan oleh pihak yang berwajib mengingat kesadaran hukum sudah ada pada diri masyarakat Indonesia. Yang menjadi permasalahan dalamkehidupanmasyarakatterhadap hukum yaitu adanya kesadaran hukum yang minim sehingga masih adaterjadi pelanggaran terhadap hukum baik disengaja maupun tidak disengajaolehmasyarakat. Norma hukum yang hidup dalam masyarakat merupakan salah satu landasan, pedoman dan payung hukum bagi rakyat Indonesia karena Bangsa Indonesia menghendaki kesadaran hubungan antara manusia dengan Tuhan sebagai maha pencipta, antara manusia dengan alam lingkungannya, keserasian hubungan antara manusia yang satu dengan manusia lainnya yang hidup bersama dalam masyarakat, juga keselarasan antara cita-cita hidup secara fisik material dengan mengejar kebahagiaan rohani, mental dan spiritual.

Dalam kehidupan bermasyarakat yang selaras serasi dan seimbang, manusia memerlukan aturan atau norma untuk mengatur tingkah laku agar terwujudnya ketertiban sosial bagi selurh masyarakatnya, hubungan dalam pergaulan yang baik dan seimbang, dengan tujuan agar tidak terjadinya benturan di antara mereka. Dalam situasi seperti inilah norma hukum sangat diperlukan oleh masyarakat sebagai pedoman atau patokan yang merupakan petunjuk hidup untuk menghindari terjadinya benturan/konflik sebagai akibat dari berbagai ragam kepentingan kebutuhan hidup manusia dalam masyarakat yang bersifat kompleks. Norma hukum diberlakukan, diterapkan, ditegakkan dan ditaati oleh masyarakat sebagai petunjuk arah bagi setiap manusia agar dapat bertindak sesuai harapandantujuankehidupanbermasyarakat dengan menjalankan perbuatan-perbuatan yang baik yang tetapberpegangteguhpadakebenaran. Hukum 
yang berlaku dalam masyarakat tidak jatuh begitu saja dari langit, tetapi tumbuh dan berkembang bersama pertumbuhan masyarakatnya (Satjipto Rahardjo dalam Achmad Ali, 2012 : 41)

Norma hukum yang berlakudalammasyarakatsangat menentukan terwujudnyaketentraman, ketertiban dan keamanan bagi masyarakat terutama masyarakat yang sering mengalami permasalahan-permasalahan sebagai akibat kebutuhan hidup yang selaluberkembangdan sangat memerlukan perlindungan terhadap kepentingan manusia.Pergaulan manusia yang satu dengan manusia lain dalam masyarakat dengan latar belakangsosialdanbudaya yang berbeda, pola hidup masyarakat berbeda, jenis-jenis perilakumanusia yang dianggap sesuai ternyata berbeda-beda karena aturan-aturan yang diberlakukan juga berbeda atau berlainan. Jelas bahwa dalam masyarakat kompleks kadang-kadang ada norma-norma atau nilai-nilai yang berbeda bahkan berlawanan. Kesenjanganaturanhukum mudah timbul sebagai akibat terjadinya kemajemukan hukum yang ada dalam masyarakat. Kesenjangan hukum terjadi karena perbedaan persepsi antara lembaga penegak hukum yang bertugas sebagai fungsionaris hukum yang bertugas melaksanakan hukum dengan warga masyarakat sebagai pengguna hukum. Oleh karena itu hukum yang berlakusenantiasaharusdikaitkandenganmasyarakatdimanahukumituhidup, berkembangdanbekerja. Hukum adat dengan hukum agama yang hidupdalammasyarakatselaluberdampingandansalingmendukungsertasalingbertautantermasukhu kumadat Bali danhukum agama Hindu selaluberdampingandansalingbertautan, bahkansulitdipisahkan walaupun pada intinya antara hukum adat dengan hukum agama tetap masih ada perbedaannya.

Manusia hidup berkelompok dalam masyarakat yang hidupbersamawalaupunsalingberdampingan sering menemukan perubahan-perubahan dalam hidupbermasyarakatbahkansampaiadanyaperbedaan-perbedaanpandangan sebagai akibat pengaruhglobalisasiataumodernisasi sehingga diperlukan norma hukum yang mampu menampung dan mengarahkan kebutuhan-kebutuhan yang sesuai dengan kesadaran masyarakat.Dalammasyarakathukum yang hidup dalam masyarakat baik hukum agama, hukum adat dan hukum negara berfungsi sebagai sarana kontrol sosial kehidupan masyarakat. semua hukum yang berlaku ini untuk menjaga agar masyarakat tetap berada dalam pola tingkah laku yang diterima baik oleh hukum, masyarakat maupun lingkungan masyarakat, termasuk oleh hukum dan peraturan perundang-undangan lainnya yang berlaku. Hukum yang berlaku mengontrol apakah suatu perbuatan atau tindakan itu sudah sesuai atau 
tidakdengankehendakmasyarakatdanhukum.Hukum yang berlakutumbuh bukan dari perbuatan pemerintah, melainkandarifakta-faktasosial di dalamsuatukomunitastermasuknilai-nilai yang hidupdalammasyarakat. Aturan hukum merupakan pencerminan kaidah-kaidah ekonomi dan moral, yang didasarkan pada pengakuan masyarakatnya tentang kesignifikanannya bagi ikatan kemasyarakatan. (Achmad Ali, $2012: 42$ )

Manusia yang hidup bersama dan bekerjasama dalam masyarakat untuk mencapai keinginan-keinginan mereka bersama yang hidup bergaul cukup lama. Masyarakat Hindusebagaimasyarakattransmigrasiasal Bali yang berada di kecamatanBasarangsudahhidupbermasyarakatcukup lama. Pada kehidupan masyarakat hukum agama dan hukum adat yang diterapkan tumbuh sejalan dengan pengalaman warga-warga masyarakat dalam proses interaksi sosial. Masyarakat mempunyai hubungan dalam keluarga dan dalam masyarakat setempat sangat kuat, hal ini disebabkan oleh karena adanya orientasi yang sangat kuat bahwa kehidupan manusia tergantung pada sesamanya dan saling membutuhkan. Kehidupan berkelompok tersebut ditunjang oleh ikatan kekerabatan dan ikatan tempat kediaman yang sama sehingga sangat terasa pengaruh daripada keluarga-keluarga luas maupun kelompokkelompok besar yang terikat pada persamaan wilayah.

Masyarakat Hindu Bali yang berada di Kecamatan Basarang membentuk organisasi sosial baik itu PHDI maupun Banjar Adat yang ada dalam masyarakat pada pokoknya didasarkan atas tradisi, adat istiadat yang berbentuk turun temurun menurut dan telah mentradisi. Pemimpin masyarakat dalam suatu kelompok masyarakat dipilih berdasarkan kesepakatan dan memilih pemimpin yang dianggap mampu memimpin serta mempunyai kewibawaan yang mampu memimpin dimana masyarakat lebih dominan mengikuti perintah dan petunjuk dari pemimpinnya. Kewibawaan seorang pemimpin masyarakat dalam organisasi sosial masih besar pengaruhnya dan diharapkan mempunyai kemampuan untuk mengikuti perkembangan masyarakat dan mampu menjaga perkembangan masyarakat agar tidak menyimpang dari normanorma dan nilai-nilai.Organisasi sosial masyarakat Transmigrasi asal Bali di kecamatan Basarang lebih dikenal dengan nama Banjar Adat yang tumbuh dan berkembang sepanjang perjalanan sejarah dan selama berada di Basarang yang memiliki satu kesatuan tradisi dan tata krama pergaulan hidup masyarakat secara turun temurun dalam ikatan kahyangan tiga atau kahyangan desa atau kahyangan tunggal yang mempunyai wilayah tertentu serta berhak mengatur rumah tangganya sendiri telah memberikan kontribusi yang sangat berharga terhadap 
kelangsungan kehidupan bermasyarakat. Banjar Adat sebagai kesatuan masyarakat hukum adat yang dijiwai oleh ajaran agama Hindu dan nilai-nilai budaya yang hidup pada masyarakat Hindu Bali sangat besar peranannya dalam bidang agama dan sosial budaya sehingga perlu diayomi, dilestarikan, diberdayakan dan dikembangkan.

Lancarnya kegiatan masyarakatTransmigrasiasal Bali yang beragamaHindu di Kecamatan Basarang diperlukan pemimpin dalam organisasi Parisada Hindu Dharma Indonesia Kecamatan Basarang untuk melingkup 4 (empat) Desa yaitu Desa Lunuk Ramba, desa Bungai Jaya, desa Basarang Jaya dan desa Batu Nindan, dari keempat desa ini ada dibentuk Banjar Adat yang berjumlah 7 (tujuh) banjar adat yaitu Banjar Merta Sari Desa Batu Nindan, Banjar Dharma Santi Desa Basarang Jaya, Banjar Kerta Wana Desa Basarang Jaya, Banjar Setia Dharma Desa Basarang Jaya, Banjar Bhakti Dharma Desa Lunuk Ramba, Banjar Suka Dharma Desa Bungai Jaya dan Banjar Suka Duka Desa Bungai Jaya. Setiap banjar adat dipimpin oleh seorang pemimpin yang disebut Kelihan Adat yang memiliki tugas untuk memimpin masyarakat adatnya agar tercipta suasana yang damai dan tentram. Pada masyarakat kepercayaan kuat pada kekuatan-kekuatan gaib yang berpengaruh pada kehidupannya. Pada masyarakat dengan pola pikir yang sederhana tersebut warga-warganya merasa dirinya sebagai bagian dari alam lingkungannya dan segala tingkah lakunya dia harus memperhitungkan kekuatan-kekuatan gaib yang tidak tampak. Untuk mencapai kebahagiaan hidup maka seseorang harus menyesuaikan diri dengan tata cara sebagaimana telah ditetapkan oleh alam sekitarnya. Alam pikiran tersebut menyebabkan timbulnya anggapan-anggapan bahwa yang paling penting adalah menjaga adanya keserasian antara dunia luar dengan dunia gaib, antara manusia dengan alam lingkungannya serta antara masyarakat dengan warga-warganya.

Begitubanyakadanyaaturan atau norma hukum yang berlaku dalam masyarakat namun yang paling penting hukum yang diberlakukan tentu norma hukum yang di bawa sendiri sebagai kesatuan tradisi dan tata krama pergaulan hidup masyarakat secara turun temurun dalam ikatan kahyangan tiga atau kahyangan desa atau kahyangan tunggal. Disamping itu norma hukum lainpun tetap berdampingan dalam penegakan hukum adatnya sendiri, yaitu hukum adat setempat yang tentu perlu ditegakkan. Oleh karena itu masyarakat perlu memahami bagaimana mentaati hukum adatnya sendiri dan bagaimana cara mentaati hukum adat setempat yang berlaku. 


\section{Cara Kelompok Masyarakat Transmigrasi Asal Bali Dalam Mentaati Norma Hukum Terutama Hukum Adat dan Hukum Agama Yang Dibawa Dengan Hukum Adat Setempat Di Kecamatan Basarang.}

Kehidupan masyarakat Transmigrasi asal Bali yang berdomisili di Kecamatan Basarang Kabupaten Kapuas selalu hidup bergaul dan berbaur dengan masyarakat daerah lainnya. Namun sebagai masyarakat yang berkelompok tentunya masyarakat Hindu Bali yang berada di Kecamatan Basarang memiliki tradisi dan strategi yang tersendiri dalam hidup bermasyarakat. Untuk mendapatkan data hasil penelitian ini, penggalian data dilakukan oleh peneliti yang menekankan pada indikator sebagai berikut : (a). Peraturan Hukum Masyarakat Hindu Bali; (b). Mentaati Peraturan Hukum Adat Masyarakat Dayak; (c). Cara Mentaati Hukum Yang Hidup Dalam Masyarakat.

\subsection{Peraturan Hukum Masyarakat Hindu Bali.}

Setiap kelompok manusia yang hidup bermasyarakat dalam suatu daerah memiliki suatu budaya, tradisi dan norma yang dilakukan secara berulang-ulang dalam kehidupan bermasyarakat. Norma-norma tersebut dijadikan pedoman dan dipahami oleh setiap orang apalagi para pemimpin dan tokoh-tokoh masyarakat, salah satunya adalah peraturan hukum masyarakat Hindu Bali yang lebih dikenal dengan sebutan Awig-Awig.Dalam ketentuanketentuan peraturan hukum tersebut selalu akan ditemukan adanya norma atau kaidah yang memberikan larangan atau keharusan yang membatasi hak-hak warga masyarakat sebagai perseorangan dan mengatur haknya terhadap orang lain, sehingga terdapat ketertiban hukum masyarakatnya, disamping itu adanya sanksi yang mengatur terhadap pelanggaran norma atau kaidah yang telah diatur tersebut. Setiap masyarakat memiliki tata aturan yang sangat berperan untuk mengatur kelakuan pergaulan hidup setiap warga masyarakatnya agar tercipta suasana yang nyaman, sejuk sehingga masyarakatnya tetap seimbang, menurut Bapak I Wayan Miarsa dalam hasil wawancara dengan peneliti mengatakan bahwa : Masyarakat Hindu Bali yang berada di kecamatan Basarang telah memiliki peraturan khusus masyarakat Bali yang berupa AwigAwig yang diberlakukan dalam kelompok masyarakat Bali. Awig-awig ini dijadikan pedoman oleh masyarakat Bali dan kami selaku pengurus Parisada selalu memberikan nasehat dan pandangan agar masyarakat kami mentaati aturan yang ada dalam Awig-Awig tersebut.(wawancara pada tanggal 13 Oktober 2016) 
Untuk terciptanya suasana yang sejuk dalam lingkungan masyarakat aturan Awig-Awig diterapkan dalam masyarakat dengan selalu mengutamakan adanya musyarawah dan mufakat, baik dalam hubungan keluarga, hubungan dalam kekerabatan dan bertetangga termasuk juga dalam kegiatan pekerjaan masyarakat selalu diawali dan diakhiri dengan musyawarah dan mufakat. Hal ini dipertegas oleh Bapak I Wayan Sindra dalam hasil wawancara dengan peneliti yang mengatakan bahwa : Kelompok masyarakat Bali telah memiliki peraturan khusus masyarakat Bali yang ada di Kecamatan Basarang, hukum Agama Hindu Bali, kami laksanakan dengan baik, kami selalu taat dan tunduk untuk menjalaninya, apabila terjadi permasalahan kami selesaikan dengan musyarakat mufakat untuk menjaga hubungan yang harmonis tanpa merugikan pihak-pihak lainnya. (wawancara pada tanggal 11 Oktober 2016)

Setiap manusia yang hidup dalam suatu kelompok masyarakat pasti memiliki suatu peraturan hukum yang dijadikan dasar pijakan dalam berperilaku. Manusia yang hidup dalam masyarakat supaya hidup bersama dan sungguh merupakan hidup bermasyarakat yang teratur mereka harus mengatur tingkah laku setiap orang agar tidak terjadi kekacauan, untuk itu diperlukan peraturan-peraturan terhadap kelakuan. Dalam masyarakat ada sejumlah besar peraturan kelakuan dan kebanyakan orang biasanya menyesuaikan kelakuannya pada peraturanperaturan tersebut. Peraturan-peraturan kelakuan tersebut yaitu ada dalam aturan kebiasaan masyarakat setempat. Berdasarkan hasil wawancara peneliti dengan Bapak I Ketut Mudarya yang pada intinya mengatakan bahwa :Masyarakat Hindu Bali yang berdomisili di Kecamatan Basarang telah memiliki peraturan hukum adat Bali, kami melaksanakan hukum adat dan juga hukum Hindu Bali, namun tidak terlalu kentara jelas antara Hukum Adat dengan Hukum Hindu, mengingat Hukum Hindu telah berasimilasi dengan Hukum Adat Bali. (wawancara pada tanggal 14 Oktober 2016)

Sebagai masyarakat yang selalu hidup berdampingan dengan sesamanya tentu memiliki aturan yang telah mentradisi yang sudah melekat pada sistem kehidupan masyarakat. hal senada juga disampaikan oleh Bapak I Wayan Suarna dalam hasil wawancara dengan penulis yang mengatakan bahwa, sebagai masyarakat Transmigrasi yang berasal dari Bali sudah tentu memiliki adat tersendiri yang sudah kita warisi, kita ikuti dan kita laksanakan sesuai dengan aturan yang ada. (wawancara pada tanggal 12 Oktober 2016)

Aturan hukum baik hukum adat, hukum agama maupun hukum negara sangat perlu ditegakkan, apalagi masyarakat Transmigrasi asal Bali tentu memiliki aturan tersendiri, 
sebagaimana hasil wawancara dengan Bapak I Wayan Lestor dengan peneliti yang mengatakan bahwa, masyarakat Bali memiliki hukum adat, kami pada dasarnya wajib melaksanakan setiap aturan adat Hindu dari Bali, demikian pula dalam hidup bermasyarakat kami harus menghormati aturan adat yang berlaku di daerah setempat. (wawancara pada tanggal 13 Oktober 2016)

Berdasarkan Teori Sistem Sosial dari Talcott Parsons bahwa Sebagai makhluk individu manusia terikat oleh sistem dan sebagai makhluk sosial, manusia juga terikat oleh sistem bahkan berbagai sistem, karena prilaku manusia pada dasarnya digerakkan oleh sistem itu. Berjalannya sistem tentu memiliki aturan yang harus dijadikan dasar dalam berperilaku, dasar ini adalah peraturan hukum masyarakat Bali yang dijadikan suatu sistem. Dengan demikian masyarakat Transmigrasi asal Bali tetap memiliki peraturan khusus yang diterapkan yang memang sudah di bawa dari daerah asal yaitu pulau Bali sebagai tradisi hukum adat secara turun temurun.

\subsection{Mentaati Peraturan Hukum Adat Masyarakat Dayak.}

Aturan hukum adat sangatlahdiperlukanolehmasyarakatsetempat sebagai payung dan sebagai pedoman yang merupakanpetunjukhidupuntukmenghindariterjadinyabenturan/perselisihan mengingat berbagaimacam ragamkepentingankebutuhanhidupmanusiadalambermasyarakat. Sebagai masyarakat yang kental akan tradisi secara turun temurun aturan hukum yang diharapkan tentulah hukum adat yangdiberlakukandan ditaatiolehmasyarakat pendukunguntukmemberipetunjukkepadamanusiabagaimanaseseorangharusbertindakdalammasy arakatsertaperbuatan-perbuatanmana yang harusdijalankandanperbuatan-perbuatanmana pula yang harusdihindari. Semua masyarakat yang berdasarkan dari kesukuannya pasti memiliki hukum adat baik itu masyarakat Bali, masyarakat Jawa maupun masyarakat Dayak. Sebagai penduduk asli masyarakat Dayak pasti memiliki hukum adat, sehingga dalam pelaksanaan hukum adat tentulah hukum adat tersebut saling berdampingan satu sama lainnya. Menurut Bapak I Wayan Miarsa dalam wawancara dengan peneliti yang mengatakan bahwa :Sebagai masyarakat yang tinggal di Kalimatan Tengah tentu kita juga mentaati hukum adat setempat yaitu hukum adat Dayak karena dalam segala sesuatu hal, kegiatan upacara dan kegiatan ritual yang lain selalu diimbangi dengan adat setempat, disamping itu dalam lingkungan kami hukum adat Dayak diberlakukan dengan tujuan agar saling menjaga dan saling menghormati. (wawancara pada tanggal 13 Oktober 2016) 
Aturan adat tentu sangat menentukan dalam penegakan ketertiban, keamanan serta kenyamanan hukum bagi masyarakat adat terutama masyarakat yang sering mengalami permasalahan-permasalahan sebagai akibat kebutuhan hidup yang sangat memerlukan perlindungan kepentingan manusia dalam masyarakat. Masyarakat sering menemukan perubahan-perubahan dalam kehidupannya sebagai akibat modernisasi sehingga diperlukan aturan adat yang mampu menampung dan mengarahkan kebutuhan-kebutuhan yang sesuai dengan kesadaran masyarakat. Disamping mentaati hukum adat sendiri kita juga harus mentaati hukum adat setempat, hal ini dipertegas oleh bapak I Ketut Mudarya dalam wawancara dengan peneliti yang mengatakan bahwa, kita sebagai bagian dari masyarakat Kalimatan Tengah tentu mentaati hukum adat setempat, karena kita berada di bumi Kalimantan mengikuti slogan “dimana bumi dipijak disana langit dijunjung”. (wawancara pada tanggal 14 Oktober 2016)

Nah, sebagai warga masyarakat kita harus memahami tentang kaidah-kaidah yang berlaku, kaidah mana yang mampu mencerminkan rasa keadilan masyarakat, kaidah mana yang dalam pelaksanaannya dilaksanakan secara sukarela oleh warga masyarakat tanpa adanya paksaan dari pihak lain. Mentaati hukum yang hidup dalam masyarakat agar tercipta rasa aman dan tentram hal ini disampaikan oleh Bapak I Wayan Suarna dalam wawancara dengan peneliti yang mengatakan bahwa, kita sebagai orang Bali sedikit banyaknya agar mengenal hukum adat masyarakat Dayak, kita sebagai warga pendatang sebaiknya taat dan patuh dengan hukum adat dimana kita tinggal agar kehidupan kita aman dan selalu hidup rukun dan damai dalam bermasyarakat. (wawancara pada tanggal 12 Oktober 2016)

Sebagai masyarakat yang berjiwa Pancasilais untuk menegakkan keadilan terhadap masyarakat disinilah dituntut kepada para aparat atau lembaga yang berwenang untuk memahami dan mampu menerapkan Hukum Adat agar dapat menegakan Hukum Adat sesuai dengan ketentuan dan perasaan keadilan masyarakat. Yang pasti semua hukum pasti ingin menegakkan keadilan dan ketentraman bagi masyarakatnya oleh karena itu pentaatan terhadap hukum yang berlaku sangat perlu ada pada setiap warga masyarakatnya. Berdasarkan hasil wawancara peneliti dengan Bapak I Wayan Lestor yang mengatakan bahwa, kita tidak terlalu banyak mengetahui mengenai hukum adat masyarakat Dayak, sebagai masyarakat yang ada diperantauan tentunya harus menghormati hukum adat setempat selagi hukum tersebut tidak bertentangan dengan ajaran agama. (wawancara pada tanggal 13 Oktober 2016) 
Sebagai warga negara dan sebagai warga masyarakat Kalimantan Tengah, masyarakat Transmigrasi asal Bali yang sudah lama berdomisili di Kalimantan Tengah tradisi yang dikembangkan dan dijunjung oleh Masyarakat Hindu Bali yang berada di Kecamatan Basarang dalam adat istiadat yang merupakan pelaksanaan ajaran agama Hindu sehingga adat istiadat yang dirasakan oleh masyarakat Hindu sebagai cara hidup menurut ajaran agama Hindu, sehingga pelaksanaan adat dan penerapan sanksi adatnya memperhatikan aspek kerukunan dan rasa kepatutan dalam masyarakat, juga mengandung upaya pendidikan kepada krama banjar sehingga merupakan upaya penyadaran dan tuntunan, yang paling penting sanksi yang diterapkan disesuaikan dengan tingkat kesalahan dan memperhatikan serta memperhitungkan keseimbangan dan kesucian lingkungan.

Disamping itu sebagai warga masyarakat Kalimantan Tengah masyarakat Hindu Bali juga mentaati hukum adat Dayak setempat yang sama dalam hal penerapan aturan hukumnya, sebagaimana hasil wawancara peneliti dengan Bapak I Wayan Sindra yang mengatakan bahwa :Sebagai warga masyarakat kami memang mengenal hukum adat masyarakat Dayak yang ada di Kecamatan Basarang, kami juga sangat mentaatinya karena kami hidup berdampingan dengan masyarakat Dayak yang ada diKecamatan Basarang, dan untuk hukum adat Dayak kami selalu konsisten untuk menjalaninya. (wawancara pada tanggal 11 Oktober 2016)

Hukum adat yang berlaku dalam masyarakat kalau kita perhatikan dalam perkembangan corak dan sistem hukum adat tetap menunjukkan corak yang tradisional, keagamaan, kebersamaan konkrit, terbuka dan sederhana. Bercorak tradisional ini berarti bersifat turun temurun dari jaman nenek moyang sampai kepada anak cucu sekarang masih tetap berlaku dan dipertahankan oleh masyarakat yang bersangkutan. Kaidah-kaidah yang dijadikan hukum tersebut perlu dipahami oleh setiap orang apalagi para pemimpin dan tokoh-tokoh masyarakat, salah satunya adalah hukum adat.Dalam ketentuan-ketentuan peraturan hukum Adat selalu akan ditemukan adanya norma atau kaidah yang memberikan larangan atau keharusan yang membatasi hak-hak warga masyarakat sebagai perseorangan dan mengatur haknya terhadap orang lain, sehingga terdapat ketertiban hukum, disamping itu adanya sanksi yang mengatur terhadap pelanggaran norma atau kaidah yang telah diatur tersebut. Setiap masyarakat adat memiliki tata aturan yang sangat berperan untuk mengatur kelakuan pergaulan hidup setiap warga masyarakatnya agar tercipta suasana yang nyaman, sejuk sehingga masyarakatnya tetap 
seimbang, keseimbangan itu tidak saja menyangkut dunia lahir dan gaib termasuk pula keseimbangan antar golongan manusia baik seluruhnya maupun perorangan.

Berdasarkan Teori Tindakan Sosial dari Max Weber bahwa, hal-hal yang dilakukan individu atau kelompok di dalam interaksi dan situasi sosial tertentu, yang ditekankan bukanlah tindakan individu, tetapi norma-norma dan nilai-nilai sosial yang menuntun dan mengatur tingkah laku. Mentaati peraturan hukum bagi masyarakat trasmigrasi asal Bali merupakan suatu tindakan yang harus dilakukan oleh setiap warga masyarakat sebagai suatu tindakan sosial yang dilandasi oleh aturan hukum yang berlaku termasuk hukum adat setempat.

\subsection{Cara Mentaati Hukum Yang Hidup Dalam Masyarakat.}

Setiap orang dalam hidup bermasyarakat tentu memiliki keinginan untuk mentaati aturan hukum yang berlaku, disamping itu setiap manusia dalam masyarakat mempunyai kodrat untuk hidup bersama-sama dengan manusia lainnya dalam hidup bermasyarakat. Pergaulan hidup inilah (sebagai mahluk hayati) menjadi manusia sebenarnya, artinya mahluk yang berperasaan sosial dengan sifat-sifat yang dapat dibentuk lebih lanjut, sifat-sifat yang dibawa dari lahirnya oleh karena pengalamannya bergabung menjadi suatu kesatuan yang lebih tinggi. Dalam kehidupan berkelompok itu terjadi rasa persatuan yang kuat sehingga para anggota kelompok dapat mempertahankan kesatuannya. Hubungan individu sebagai warga suatu kelompok dengan kelompoknya saling mempengaruhi. Pada suatu saat, perilaku individu di pengaruhi oleh kelompok yang menjadi anggotanya. Sebaliknya, individu dapat juga mempengaruhi kelompoknya sehingga terjadilah dinamika kelompok. Hal itu menunjukkan bahwa kehidupan kelompok bukanlah statis, tetapi berada dalam keadaan berkembang secara dinamis didalam kelompoknya. Kelompok sosial merupakan kesatuan sosial yang terdiri dari kumpulan individu-individu yang hidup bersama dengan mengadakan hubungan timbal balik yang cukup intensif dan teratur, sehingga daripadanya diharapkan adanya pembagian tugas, struktur, serta norma-norma tertentu yang berlaku bagi mereka. Oleh karena itu setiap manusia dalam masyarakat wajib untuk mentaati aturan yang berlaku. Berdasarkan hasil wawancara peneliti dengan Bapak I Wayan Sindra yang mengatakan bahwa : Cara mentaati hukum dengan jalan tidak melanggar larangan yang telah dibuat bila melanggar maka dengan penuh tanggung jawab untuk menjalaninya, begita juga terhadap hukum adat Dayak kami tetap mentaatinya dengan selalu bekerjasama, tidak melanggar aturan adat Dayak, bila melanggar maka dengan iklas dan tanggung jawab menjalaninya. (wawancara pada tanggal 11 Oktober 2016) 
Selama krama Banjar Adat mendukung Banjar Adat dan lembaga Parisada dan tetap pada Sraddha dan Bhakti pada ajaran agama Hindu dan Budaya Bali, maka selama itu adat dan Banjar Adat tetap ajeg serta memiliki ketahanan yang mantap untuk berhadapan dengan berbagai tantangan dan pengaruh dari luar. Keadaan yang demikian sangat diharapkan oleh masyarakat Hindu di Basarang yang selalu disampaikan kepada generasi berikutnya. Karakteristik Masyarakat Hindu sangat nampak dari kehidupan agama Hindu, adat dan budayanya yang menyatu padu dalam suasana yang harmonis, ikatan ini terwadahi ke dalam institusi tradisional yang dinamakan Banjar Adat yang menjadi basis atau kantong budaya, agama dan ekonomis. Masih eksisnya Banjar adat pada masyarakat Hindu sebagaimana pemerintah juga menyadari bahwa setiap daerah di Indonesia memiliki karakterisrik sendiri dimana semua potensi daerah ini tetap dipelihara. Sesuai hasil wawancara dengan bapak I Wayan Lestor yang mengatakan bahwa :Cara untuk mentaati norma hukum yang berlaku, baik itu hukum agama hukum adat Bali maupun hukum adat Dayak sudah tentu kita mentaati setiap aturan yang telah ditetapkan dan disepakati oleh pengelingsir dan pengurus adat beserta warga yang ada di setiap banjar, khususnya kami warga banjar Kertawana. Begitu juga terhadap hukum adat setempat kita harus mentaatinya dan menghormati setiap aturan yang telah ditetapkan adat masyarakat setempat. (wawancara pada tanggal 13 Oktober 2016)

Menghormatinorma -normahukum yang berlakudalammasyarakat agar hubungankehidupanbersamadalammasyarakattetapharmonis. Agar hubungan kehidupan bermasyarakat tetap harmonis setiap warga masyarakat wajib untuk menghormati norma hukumnorma hukum yang hidup dalam masyarakat, seimbang dan harmonisnya hubungan masyarakat diperlukan pentaatan pada aturan yang berlaku, sebagaimana hasil wawancara peneliti dengan Bapak I Wayan Miarsa yang mengatakan bahwa :Kita masyarakat Hindu Bali yang ada di Basarang harus mentaati aturan hukum yang ada, cara kami mentaati hukum adat/hukum Hindu Bali yaitu dengan cara memahami terlebih dahulu dan mensepakati hukum adat yang diterapkan, yaitu contohnya pada upacara pernikahan seorang pria melamar wanita itu wajib untuk membawa perlengkapan peminangan apabila tidak lengkap/tidak sesuai maka akan dikenakan sanksi berupa penundaan pernikahan. (wawancara pada tanggal 13 Oktober 2016)

Hubungansetiap orang dalammasyarakatdapatlebihbaikdalamkehidupanbermasyarakatbila masyarakat sendiri mentaati aturan dari pada tidak mentaatinya apalagi sampai melanggarnya, aturan hukum masyarakat 
manapun yang diberlakukan kita wajib untuk mentaatinya, hal ini dijelaskan lebih lanjut oleh Bapak I Wayan Miarsa yang mengatakan bahwa, kita juga harus mentaati hukum adat masyarakat lainnya, cara kami mentaati hukum adat Dayak yaitu dengan cara mengikuti aturan yang diterapkan di lingkungan kami, contoh pembersihan desa setempat yang menggunakan adat Dayak (mapas lewu) / dalam bahasa Bali mecaru desa pakraman, dan itu dikenakan biaya yang dikumpulkan di desa / ketua adat masing-masing. (wawancara pada tanggal 13 Oktober 2016)

Masyarakatmenginginkankehidupan yang lebihbaik, sehinggamerekamerasamemerlukanaturanhukumuntukmengaturnya. Secara umum semua aturan hukum memiliki tujuan yang sama yaitu sama-sama menciptakan keamanan, ketertiban, ketentraman, keadilan serta keseimbangan lahir dan bhatin, sehingga semua aturan hukum memiliki tujuan yang sangat baik. Aturan hukum yang baik adalah aturan hukum yang mampu hidup dan terima di tengah-tengah kehidupan masyarakat, sebagaimana hasil wawancara peneliti dengan Bapak I Ketut Mudarya yang pada intinya mengatakan bahwa :Dalam hidup bermasyarakat kami sangat mentaati hukum adat/hukum Hindu Bali, karena kedua hukum itu telah berasimilasi dan diimplementasikan dalam organisasi Banjar, begitu juga terhadap hukum adat Dayak kami bermasyarakat dengan jalan mematuhi aturan-aturan hukum Adat Dayak Kalimantan Tengah diberbagai kehidupan sosial masyarakat misalnya dari segi tata cara perkawinan, peminangan dan lain-lainnya. (wawancara pada tanggal 14 Oktober 2016)

Untuk terwujudnya kedamaian dalam hidup bermasyarakat kehidupan manusia dalam masyarkat tentu diliputi oleh berbagai norma-norma yaitu peraturan tingkah laku manusia dalam masyarakat. Sejak masih kecil kita tentunya sudah dibatasi oleh berbagai peraturan hidup yang membatasi kita berbuat dengan sekehendak hati kita, awalnya peraturan itu berlaku dari dalam lingkungan keluarga kita (tidak boleh nakal, tidak boleh pulang malam, disiplin dll). Selanjutnya berlaku juga dalam lingkungan masyarakat bahkan sampai meluas keberlakuannya hingga berlaku dalam sebuah wilayah negara. Namun demikian norma tersebut bermanfaat bagi diri sendiri sebagai perlindungan kepentingan pribadi individu dalam masyarakat. Karena setiap norma memiliki tujuansupaya kepentingan masing-masing warga masyarakat juga ketentraman dalam kehidupan bermasyarakat itu bisa dijalankan dan dijaga atau dilindungi dengan baik. Untuk tercapai kedamaian norma hukum itulah yang harus kita taati. Hal ini disampaikan oleh Bapak I Wayan Suarna dalam wawancara dengan peneliti yang mengatakan bahwa :Sebagai masyarakat Bali tentu kita mentaati adat/hukum adat Bali, caranya tentu kita laksanakan sesuai 
dengan norma-norma yang ada, untuk mentaati hukum adat setempat dengan cara menghormati hukum adat Dayak sehingga kita dapat hidup berdampingan dan harmonis, kita tidak boleh mengabaikan adat Dayak yang ada di sekitar kita. (wawancara pada tanggal 12 Oktober 2016)

Berdasarkan Teori Tindakan Sosial dari Max Weber bahwa, hal-hal yang dilakukan individu atau kelompok di dalam interaksi dan situasi sosial tertentu, yang ditekankan bukanlah tindakan individu, tetapi norma-norma dan nilai-nilai sosial yang menuntun dan mengatur tingkah laku. Tindakan adalah salah satu cara, cara disini yaitu cara mentaati hukum yang berlaku yang harus dilaksanakan oleh Masyarakat Hindu asal Bali. Interaksi sosial merupakan syarat utama bagi terjadinya aktivitas sosial dan hadirnya kenyataan sosial sebagai suatu yang didasarkan pada motivasi individu dan tindakan-tindakan sosial. Ketika berinteraksi, seseorang atau kelompok sebenarnya tengah berusaha atau belajar bagaimana memahami tindakan sosial yang mereka lakukan.

\section{Penutup}

Anggota masyarakat wajib untuk mentaati norma hukum yang berlaku, dengan cara mentaati aturanya, melaksanakan perintahnya dan menjauhi larangannya. Aturan hukum memiliki tujuan yang sama yaitu sama-sama menciptakan keamanan, ketertiban, ketentraman, keadilan serta keseimbangan lahir dan bhatin, sehingga semua aturan hukum memiliki tujuan yang sangat baik. Aturan hukum yang baik adalah aturan hukum yang mampu hidup dan terima di tengah-tengah kehidupan masyarakatAgar hubungan kehidupan bermasyarakat tetap harmonis setiap warga masyarakat wajib untuk menghormati norma hukum-norma hukum yang hidup dalam masyarakat, Mentaati hukum yang hidup dalam masyarakat agar tercipta rasa aman dan tentram.

Cara masyarakat Transmigasi asal Bali dalam mentaati Norma Hukum terutama Hukum Adat dan Hukum Agama yang dibawa dengan Hukum Adat setempat adalah dengan cara mentaati semua paraturan yang diberlakukan oleh lembaga yang berwenang, masyarakat transmigrasi asal Bali sangat mentaati hukum Hindu/adat Bali karena kedua hukum itu telah berasimilasi dan diimplementasikan dalam organisasi Banjar dan sebagai masyarakat Kalimantan Tengah masyarakat Transmigrasi asal Bali tentu juga mentaati hukum adat dayak yang berpegang teguh pada slogan dimana bumi dipijak disitu langit dijunjung. 


\section{DAFTAR PUSTAKA}

Ali Achmad \& Heryani Wiwie, 2012. Menjelajahi Kajian Empiris Terhadap Hukum, Kencana Prenada Media Group, Jakarta.

Faisal Sanapiah, Penelitian Kualitataif, Dasar dan Aplikasi, YA3 Malang, 1990

Ihroni, Antropologi Dan Hukum, Yayasan Obor Indonesia, Jakarta, 1984

JonesPip, Pengantar Teori-Teori Sosial, Yayasan Obor Indonesia, Jakarta, 2009

Moleong Lexy J., Metodologi Penelitian Kualitatif, Remaja Rosdakarya, Bandung, 2010

Narwoko J. Dwi - Bagong Suyanto, Sosiologi Teks Pengantar Dan Terapan, Kencara Prenada Media Group, Jakarta, 2010

Poloma Margaret M., Sosiologi Kontemporer, PT. Raja Grafindo Persada, Jakarta, 2010

Rahardjo Satjipto, Ilmu Hukum, Alumni, Bandung, 1986

Setiady Tolib, 2013. Intisari Hukum Adat Indonesia (Dalam kajian Kepustakaan), Alfabeta, Bandung.

Strauss Anselm \& Juliet Corbin, Dasar-Dasar Penelitian Kualitatif, Pustaka Pelajar, Yogyakarta, 2009

Soekanto Soerjono, Hukum Adat Indonesia, Jakarta, PT. Raja Grafindo Persada, 2001

Suasthawa Dharmayuda I Made, Desa Adat Kesatuan Masyarakat Hukum Adat di Propinsi Bali, Upada Sastra, Denpasar Bali, 2001

Suprayogo Imam - Tobroni, Metodologi Penelitian Sosial-Agama, PT. Remaja Rosdakarya, Bandung, 2001

Wulansari Dewi, Sosiologi Konsep Dan Teori, PT. Refika Aditama, Bandung, 2009. 
